\title{
ПОВІТОВІ ТА ВОЛОСНІ ЗЕМСТВА УКРАЇНСЬКОЇ НАРОДНОЇ РЕСПУБЛІКИ ПІД ОКУПАЦІЕЮ БІЛЬШОВИЦЬКОї РОСІї
}

\author{
Матвієнко Т. О., асистент кафедри педагогіки та суспільних наук \\ Україна, м. Полтава, Вищчий навчальний заклад Укоопспілки \\ «Полтавський університет економіки і торгівлі»
}

DOI: https://doi.org/ 10.31435/rsglobal_ws/31102018/6186

\section{ARTICLE INFO}

Received: 09 August 2018

Accepted: 25 October 2018

Published: 31 October 2018

\section{KEYWORDS}

zemstvos,

zemstvo assembly,

councils of workers,

soldiers and peasants deputies,

Bolsheviks,

aggression.

\begin{abstract}
The consequences of Bolshevik Russia aggression into Ukraine in late 1917 - early 1918 for the volosne and district zemstvos of the Ukrainian People Republic (UPR) zemstvos are analysed. The UPR was proclaimed by the Central Council on 7 November 1917 in response to the violent takeover by the Bolsheviks in Petrograd. At its territories where Bolsheviks seized power they transferred power to the councils they controlled. Local governments - zemstvos - existing here - were regarded by them as incompatible with the objectives of the socialist revolution and establishing the dictatorship of the proletariat. Typically, the Bolsheviks eliminated zemstvos leaders from their positions, and dissolved rural assemblies. For some time they used the economic apparatus of zemstvos management. However, the "revolutionary expediency" very soon prevailed over common sense and zemstvos as local population authorities were eliminated.
\end{abstract}

Citation: Матвієнко Т. O. (2018) Povitovi ta Volosni Zemstva Ukrainskoi Narodnoi Respubliky pid Okupatsiieiu Bilshovytskoi Rosii World Science. 10(38), Vol.2. doi: 10.31435/rsglobal_ws/31102018/6186

Copyright: (C) 2018 Матвієнко T. O. This is an open-access article distributed under the terms of the Creative Commons Attribution License (CC BY). The use, distribution or reproduction in other forums is permitted, provided the original author(s) or licensor are credited and that the original publication in this journal is cited, in accordance with accepted academic practice. No use, distribution or reproduction is permitted which does not comply with these terms.

Вступ. Захоплення в результаті Жовтневого збройного перевороту 1917 року у Петрограді влади в Росії більшовиками стало початком їх протистояння з Українською Центральною Радою. Як авторитетне об'єднання патріотичних сил України, та бачила іiі майбутнє автономією у складі демократичної Росії. Тому відмежувалась від нав'язаних більшовиками силових методів боротьби за владу і 7 листопада 1917 року своїм III Універсалом проголосила створення Української Народної Республіки. Вища влада в ній переходила до Центральної Ради та їі уряду Генерального Секретаріату.

У відповідь більшовики ініціювали скликання 11 грудня 1917 року у Харкові I Всеукраїнського з'їзду Рад і проголосили Україну Республікою рад робітничих, солдатських і селянських депутатів. Під іiі прикриттям радянська Росія розпочала військову агресію проти УНР. Проголошення 9 січня 1918 року IV Універсалом Центральної Ради незалежності УНР не зупинило іiі. До кінця січня 1918 року більшість території молодої української республіки була окупована військами більшовицької Росії.

Силою зброї ліквідувавши центральні органи влади УНР, окупанти взялися і за іiі місцеві органи. Серед інших у центрі їх уваги опинилися й земства - губернські, повітові та волосні, - які мали стати основою демократичної системи органів місцевого самоврядування УНР. Зрозуміло, що, навіть, ідеологічно вони були несумісними 3 планами більшовиків встановити в Україні владу підконтрольних їм органів диктатури пролетаріату - рад. Зрозуміло, що ці плани прикривалися гаслами про «інтереси українського народу». 
Окрім суспільно-політичної та практичної, тема дослідження має й науково-теоретичну актуальність. Проблема долі земств УНР опинилася на периферії уваги радянських дослідників «тріумфальної ходи радянської влади» в Україні на початку 1918 року [1-6]. Об'єктивні фундаментальні дослідження, які побачили світ після проголошення незалежності України, закцентовані переважно на суспільно-політичні та військові аспекти українсько-російського протистояння кінця 1917 року - початку 1918 року [7-10]. Лише побіжно про долю низових земських органів у період цього протистояння згадують і дослідники земств доби Української революції [11-18]. Обійшла їх увагою й авторка пропонованої статті, яка у попередній публікації про земства УНР під російською окупацією обмежилася аналізом тих процесів, які відбувалися в цей час з губернськими земствами. Тому предметом даної статті $\epsilon$ повітові та волосні земства УНР під окупацією більшовицької Росії.

Результати дослідження. Як і губернські земства, для більшовиків вони були лиш «п’ятим колесом до воза» [19, с. 35], «місцевим буржуазний апарат влади», який необхідно було замінити радами [20, с. 71]. На губернському рівні радикально так вчинити відразу після встановлення радянської влади в губернських центрах більшовики не наважувалися оскільки не мали власного апарату управління. Тому нерідко йшли на різного роду компроміси 3 губернськими земствами. На повітовому та волосному рівні, зазвичай, політика окупантів була більш прямолінійною і визначалась виключно їх ідеологічною упередженістю до земств.

Першими це відчули на собі земці Харківщини. Так, у середині лютого 1918 року озброєний солдатський загін припинив роботу Вовчанської повітової земської управи Харківської губернії. «Якийсь Канченко проголосив себе комісаром і почав арешти й обшуки», - повідомляла газета «Наша борьба» [21]. Протягом лютого 1918 року від волосних земств Харківського повіту - Золочиво, Русько-Лозової, Мерефи, Циркунової, Одноробовки - були отримані повідомлення про їх ліквідацію Радами селянських, робітничих і солдатських депутатів [22]. У Коломакській волості Валківського повіту Харківської губернії 20 лютого 1918 року відбулося спільне зібрання Ради селянських депутатів, гласних волосного земства та демобілізованих солдат. Зібрання висловило недовіру волосній управі й більшості гласних волосного земства. Ініціатори зібрання наголошували на необхідності «видалення негідних членів правлячого круга, серед якого маються чорносотенці». Волосна управа на екстреному земському зібранні вирішила скласти свої повноваження. Але присутній на зібранні матрос заявив, що «управа та гласні повинні залишатися на своїх місцях доти, доки сільський сход відкритим голосуванням обере новий склад гласних і управу». Управа погодилася тимчасово продовжувати свою роботу [23].

У Покотилівській волості Харківського повіту в кінці лютого 1918 року відбулося багатолюдне зібрання мешканців волості 3 приводу долі волосного земства. Голова Покотилівського волосного земства повідомив, що волосний революційний комітет на чолі 3 Шарковим і Чухалдіним розглядали земство як орган, який «не відповідає вимогам часу і тому підлягає ліквідації». Зібрання не підтримало їх пропозицію. Голова волосного земства у своєму виступі наголосив на тому, що «волосне земство обране всім населенням, тому похід на нього 3 боку тих або інших осіб чи окремих груп необхідно вважати домаганням особистого характеру й насиллям над волею свідомої більшості». Більшість земців, які виступали на зібранні, 3 обуренням говорили про дії більшовиків за короткий час перебування їх при владі. Натомість один із очільників волосного революційного комітету Шарков у своєму виступі вказав на те, що «найбідніша частина населення не бере участі в новому будівництві життя», і дорікав земство, що воно нічого не зробило за 50 років існування, а «радянська влада, яка є народною владою, - наголосив він, - усе зможе зробити для народу». Прихильників радянської влади на зібранні було небагато, тому була прийнята резолюція на захист земства. Прийняте рішення не влаштовувало більшовиків. Через день після зібрання ними були скликані збори найбідніших жителів Покотилівки, на яких була обрана Рада селянських депутатів на чолі із заможним домовласником Шарковим. Саме Раді були передані всі справи волосної земської управи [22].

Більшовики намагалися поширити свою владу в повітах і волостях Катеринославщини. Натомість повітові комісари, призначені ще Центральною Радою, докладали зусилля для збереження влади в повітах і волостях у земських органах влади. Зокрема, Олександрівський повітовий комісар Лазарів 26 січня 1918 року видав відозву «Всім волосним земським управам, начальникам міліції». У ній зазначав, що на теперішній стан на території УНР існує тільки одна законна влада Генерального Секретаріату та виконавці розпоряджень цієї влади - комісари, міські, земські та волосні самоврядування, обрані населенням на демократичних основах, і які діють згідно з чинним законодавством. У відозві повітовий комісар пропонував: «Так звані 
військово-революційні комітети, які, безумовно, виступають проти законів, сіють смуту в народі, повинні негайно бути ліквідовані як організації не корисні і навіть шкідливі. Ті 3 організацій або окремих осіб, які не бажають скоритися цьому розпорядженню, будуть притягатися до відповідальності» [24].

Маріупольській повітовий комісар Катеринославської губернії у зв’язку з майже щоденними повідомленнями про перевибори волосних земств, продовольчих і земельних комітетів 5 лютого 1918 року видав постанову, обов'язкову для всіх волосних земств повіту. У ній зазначалися умови, за яких були можливими перевибори: «По-перше, для перевиборів необхідна постанова сходу з указаною причиною такого рішення, по-друге, необхідна постанова всіх сільських сходів, які входять у цю волость, по-третє, у перевиборах повинно брати участь усе населення, яке має право голосу, перевибори вважаються законними, якщо в голосуванні взяла участь більшість населення» [25].

Таким чином, комісар намагався забезпечити хоча б якусь стабільність роботи земств i не допустити поширення анархії й паралічу влади на місцях, які могли спровокувати стихійні позачергові перевибори земських гласних чи просто розпуск земств.

У деяких випадках цього вдавалося досягти. Так, на зібранні Одинківської волосної ради на початку лютого 1918 року було повідомлено про приїзд в Одинківську волосну земську управу Новомосковського повіту Катеринославської губернії солдата-більшовика із заявою про скасування волосного земства. Члени Одинківського земства дали тверду відповідь: «Не ви, дядю, повинні скасовувати земство, а той хазяїн, який його зібрав. Скличте хазяїнів-селян і тоді скасовуйте, а коли нас будете розганяти, то це буде тільки насильство». На що солдатбільшовик відповів: «Ну, подивимося!»[26].

Дійсно, на Катеринославщині було чимало випадків більш радикального вирішення долі земств. Саме так розгорталися події у Верхнєдніпровському повіті на початку лютого 1918 року. Влада в повіті була захоплена Радою робітничих, солдатських і селянських депутатів. Повітового земського комісара «радянська влада арештувала й відправила за грати в Катеринослав» [27].

Загалом, у Катеринославській губернії склалася своєрідна ситуація «двовладдя». Політичну владу, спираючись на силу збройних загонів, захопили ради. Проте переважна більшість земств продовжувала функціонувати. У їх віданні залишалася розгалужена структура шкіл, лікарень, дитячих притулків тощо. Перерва у фінансуванні цих закладів соціального забезпечення призвела б до згубних наслідків. Тому багато управ просто не виконували постанов «Советов» про їх розпуск i продовжували працювати. Наприклад, у Катеринославському повіті такі волосні земські управи, як Лоцмансько-Каменська, Нікольська, Каменська, Солонянська, Сурсько-Михайлівська, Карнаухівська, Карнаухово-Хуторська, Дієвська та Романківська, не визнали більшовицької влади й продовжували безперервно працювати [28]. Подібною була картина й у губернії в цілому.

Попри більш радикальну політику більшовиків у Чернігівській губернії, подібна ситуація склалася й там. Після встановлення більшовицького панування в Чернігівській губернії було розпочато організацію органів радянської влади. Більшовик 3. Табаков згадував, що після захоплення влади «розташувались ми в приміщенні кабінету повітового земського комісара, який тихо канув у свою квартиру, задоволений тим, що про нього забули. Ми вирішили його не арештовувати» [29, с. 150]. Чернігівська рада робітничих і солдатських депутатів спробувала взяти на себе функції земської управи, але за відсутності власного апарату й досвіду «повітове земство продовжувало існувати і вело роботу під нашим негласним спостереженням», - згадував він. Через нетривалий проміжок часу більшовики ліквідували повітове земство, перетворивши його в повітовий земельний комітет.

У Новозибківському повіті Чернігівської губернії виконавче бюро Ради робітничих, солдатських і селянських депутатів 13 січня 1918 року оприлюднило циркуляр про організацію органів радянської влади. Згідно з циркуляром усі органи самоуправління повинні були працювати в повному контакті з Радами. «Ті ж органи влади, які не визнають владу Рад і підуть таким чином проти волі трудового народу, будуть переобрані», - наголошувалося в циркулярі [30, с. 64].

Більшовики не обмежувалися проголошенням циркулярів. Нерідко справа доходила до збройного захоплення управ i арештів голів управ i земських гласних. Зокрема, голова Сосницької повітової земської управи М. Шматько розповідав, що 16 січня 1918 року йому було подано відношення від комісара Сосницької ради робітничих, солдатських і селянських депутатів такого змісту: «Із моменту утворення в Сосницькому повіті радянської влади, яка відображає справжню волю найбіднішого селянства, солдат і робітників, втрачається будь-яка необхідність у паралельному існуванні будь-яких органів, які ніби-то висловлюють волю 
народу, а насправді узурпували іiі. Виходячи з цих міркувань, Сосницька повітова рада робочих, солдатських і селянських депутатів оголошує земську управу розпущеною, функції управи переходять до відповідних радянських комісарів і комісій». На виконання цього рішення давалося 24 години. У разі його не виконання радянський комісар погрожував застосувати збройну силу, яка знаходилася в його розпорядженні.

Незабаром кабінет голови управи був зайнятий збройним загоном, голова управи заарештований і відправлений під конвоєм разом із членами управи до приміщення ради. Згодом їх відпустили. Проте вже наступного дня приміщення управи було зайнято радою робочих, солдатських і селянських депутатів. Протестуючи проти свавілля більшовицької ради, Сосницька повітова земська управа заявила, що «єдиним правочинним і повноважним господарем повіту вона вважає повітове земське зібрання [...] і тільки перед таким зібранням управа вважає себе відповідальною і йому одному [погоджується - авт.] підпорядкуватися». Проте протистояти силі земці не могли. Сдине, на що вони спромоглися, - оголосили, що на час свого відсторонення знімають із себе відповідальність перед населенням за хід земського життя в повіті [31].

Більшовиків це не зупиняло. Так, на Стародубському повітовому з'їзді Рад, який проходив на початку лютого 1918 року було прийнято постанову про ліквідацію Стародубського земського зібрання. Натомість ухвалили організувати при виконавчому комітетові Рад відділи: земельний; харчовий; міліцію; земського, міського й посадського господарства [32, с. 123]. Стародубська земська управа відреагувала скликанням екстреного зібрання земських гласних і ухвалила постанову: «Зважаючи на те, що земське самоуправління обране загальним, рівним, прямим і таємним голосуванням, не підлягати вимогам Рад i пропонувати земській управі припинити роботу лише під загрозою озброєної сили, але самим не лишати своїх постів» [32, с. 123].

Водночас не всі земці витримували радикальний військово-політичний тиск на них. 21 січня 1918 року в Понорницьку волосну земську управу Кролевецького повіту Чернігівської губернії голова волосної земської управи А.С. Париста надіслав заяву, у якій указав: «Справи волосного земства знаходяться не в кращому стані. Серед населення проявляється не тільки незадоволення, але й безпідставна злоба до членів управи. Я, як голова управи, зазнаю часткові нападки і ображання, навіть були спроби побити мене». Тому голова волосної земської управи прохав звільнити його з посади й таким чином позбавити від наклепів [33].

Деякі земства Чернігівщини намагалися пристосуватися до нових політичних умов. Так, 7 лютого Путивльське повітове земське зібрання визнало владу Рад, а 23 березня 1918 року, навіть, асигнувало 6 тис. крб на потреби повітового виконавчого комітету [32, с. 124]. Зрозуміло, що це був вимушений крок, зумовлений, з одного боку, радикальною позицією більшовиків і підконтрольних їм рад щодо земств, а з іншого - усвідомленням їх очільників своєї відповідальності за підтримку соціального й господарського життя на місцях.

Після встановлення влади в Полтавській губернії більшовики приступили до створення своїх органів влади в повітах і волостях. Зокрема, у Гадяцький повіт 14 січня 1918 року прибув озброєний загін більшовиків, - повідомляла газета «Рідний край». Повітовий комісар П. Базіченко залишив свою посаду «у зв’язку з переходом влади до рук більшовиків» [34]. Рада робітничих, солдатських і селянських депутатів обрала повітовим комісаром П. Шияна [35]. Як повідомляла в січні 1918 року газета «Народная жизнь», у Костянтиноградському повіті «урядові установи захоплені більшовиками. Повітовий комісар засуджений до смертної кари [36].

У Лохвиці 22-24 січня 1918 року більшовики провели повітовий з'їзд Рад робітничих, солдатських і селянських депутатів. Головою виконкому Ради став меншовик-інтернаціоналіст Д. Прилипін. Після з’їду Рад 24 січня 1918 року відбулося надзвичайне Лохвицьке повітове земське зібрання. На ньому з ініціативи Д. Прилипіна обговорювалося питання про взаємовідносини між земствами та Радами. Голова виконкому Ради вказував, що на губернському з'їзді Рад робітничих, солдатських і селянських депутатів постановили «знищити земства й передати їх функції Радам», $\mathrm{i}$ висловлював надію, що «Лохвицьке повітове земство буде продовжувати свою роботу в контакті 3 Лохвицькою повітовою Радою». На запитання земців, що мається на увазі під висловом «контакт земства з Радою», Д. Прилипін пояснив: «У зв’язку з тим, що вся влада переходить до Рад, тому до Рад повинна перейти влада над земствами, які зобов'язані продовжувати свою роботу і підкорятися Радам». Після нетривалих дискусій голова повітового земського зібрання В.Ф. Сеник виніс резолюцію: «Рада робітничих, солдатських і селянських депутатів - організація революційна, яка займається збереженням завоювань революції i стоїть на охороні збереження прав своєї революційної демократії, а земство - організація господарська і культурно-просвітницька, обрана на широких демократичних засадах і являється у своєму складі строго демократичною». Після 
обговорення пропозиції В. Сеника земське зібрання постановило: «Продовжувати свою роботу на користь трудовому населенню повіту, а взаємовідносини між земством і Радою визначаються характером покладених на них завдань». Зрештою, Д. Прилипін змушений був піти на компроміс i запропонував: «Тимчасово до другого повітового з'їзу Рад включити до складу повітового i волосних земств представників від Рад із метою передачі після з'їзду всіх функцій земств Радам» [37]. Але під час його виступу в залу засідання увірвалася озброєна група осіб і голова зібрання оголосив його закритим. Відтак прийняти будь-яке компромісне рішення так і не вдалося.

Як наслідок, у волосних земствах повіту прокотилася хвиля відставок їх очільників та членів управ. Так, голова Чорнухівської волосної земської управи Лохвицького повіту М. Лисенко i член управи О. Гринько подали заяви про звільнення 3 посад [38]. На надзвичайному Свиридівському волосному земському зібранні Лохвицького повіту Полтавської губернії 23 січня 1918 року були заслухані заяви голови управи О.Ф. Терешкевича i членів управи Т.К. Косенка, Я.С. Редьки, С.К. Шиші про звільнення їх із посад «через неможливість працювати у створених умовах» [39].

Сповна відчули на собі земці Полтавщини й тиск з боку демобілізованих солдат, які опинилися в полоні більшовицької пропаганди й намагалися різними методами змінити склад земств. Так, на надзвичайному зібранні Лукського волосного земства Лохвицького повіту Полтавської губернії 9 лютого 1918 року обговорювали становище земства у зв'язку 3 незадоволенням солдатами волосним земством і особливо управою. Зібрання прийняло резолюцію: «По-перше, проведення перевиборів ще більше порушить роботу земства, по-друге, солдати, які знаходяться в полоні, з поверненням додому також вимагатимуть надати їм права взяти участь у виборах. Тому, - зазначалося в резолюції,- волосне земське зібрання вправі морально та юридично далі продовжувати свою роботу доти, поки більша половина солдат не повернеться 3 полону та військових частин» [40]. Того ж дня Кременчуцькому надзвичайному повітовому земському зібранню Полтавської губернії було надіслано доповідь про надання повітовій земській управі права переобрання нинішнього складу волосних земських управ і гласних. Автори доповіді пояснювали, що з проголошенням демобілізації та поверненням солдат додому на місцях із боку солдатів виникали вимоги про переобрання складу управ $\mathrm{i}$ гласних, а як головна підстава для переобрання вказувалося, що «гласні за своїми політичними поглядами не відповідають духу часу» [41].

Після встановлення радянської влади в Миргородському повіті Полтавської губернії 24 лютого (11) 1918 року було проведене надзвичайне повітове земське зібрання. Голова повітової земської управи Р.М. Ведмідь оголосив, що збори скликані за вимогою начальника польового штабу червоного українського козацтва Д. Чайки з приводу організації влади в повіті. Д. Чайка у своїй промові стверджував, що «в Україні повинна бути встановлена тільки влада робітників і селян [...], а земське самоврядування, яке обране трудовим народом, якщо почуває себе в силах іти поруч із цими організаціями, то добре - може залишатися, коли почуває, що не може творити волі трудового народу, то повинно піти геть». Далі начальник польового штабу продовжував, що для організації влади Рад у Миргороді тимчасово створений ревком i «земство повинно поруч іти з цим комітетом на підмогу пролетаріату, коли ж не буде йти поруч, то [земство - авт.] буде усунено». Потім Д. Чайка змалював долю земств після остаточного встановлення влади Рад: «Самоврядування перейдуть під відання ревкомів і тільки до нього повинні звертатися. Коли селяни скажуть, що наше самоврядування демократичне і їх задовольняє, то воно залишиться, але всі буржуазні елементи, які присмокталися до самоврядування, - повинні піти».

Також доповідач говорив про необхідність допомоги земств у налагодженні різних сфер соціально-економічного життя. Тому «воєнно-революційний комітет бажає чути голос земських зборів, чи буде воно йти назустріч, і коли так, то нам легше буде спрямовувати свою роботу. Тепер же наші завдання - взяти все господарство у свої руки, поставити контроль на млинах, фабриках, заводах та ін. Коли ви - виборці від трудового народу, то ви повинні це зробити». Далі Д. Чайка закликав земців: «Ви повинні визнати владу Рад, хто не погодиться, повинен піти із самоврядування. Ми всі рівні, ви повинні визнати братерство, забути національну сварку і як один стати під червоне революційне знамення».

Вислухавши доповідь Д. Чайки, гласний Н.М. Шейтельман від імені фракції українських соціал-революціонерів запропонував резолюцію: «Миргородські земські збори, які не раз висловлювали готовність і необхідність спиратися у своїй діяльності на організовану волю революційних мас трудового народу, і нині заявляють, що будуть виконувати покладені 
на нього обов'язки, поки народ зніме уповноваження зі своїх обранців». Резолюцію фракції земські збори одноголосно прийняли [42].

У тих повітах, де ліквідовували земства, більшовики створювали свої органи влади або призначали осіб, які були прихильні до їхньої влади або тих, якими легко було керувати. Наприклад, як згадував В. Андрієвський, у Гадяцькому повіті більшовики призначили завідуючим одного з відділів земств старого земського діяча дядька Гавагу. Колишній голова повітової земської управи взяв Гавагу на посаду портьєрним управи. «Але він не міг виконувати цієї роботи, бо був дуже сонливим і весь час спав коло одягу. Тепер він важно роз’їздив по повіту на земських конях у фаетоні i покурював собі люльку. Решта більшовицьких повітових і міських комісарів була в тім же роді» [43, с. 176].

У Волинській губернії, як зазначав О. Дем'янюк, уже до кінця 1917 року більшість повітових міст перебувала під впливом більшовиків i демобілізованих солдат, які їх підтримували [44, с. 135]. Підконтрольні їм Ради почали оголошувати про перехід влади на місцях до них. Більшовики використали солдатські багнети для фізичного усунення земських органів. Зокрема, у доповіді Рівненської земської управи повітовому зібранню зазначалося, що 27 грудня 1917 року більшовиками був заарештований «Рівненський голова управи Сумневич, а дещо раніше замісник голови Денисенко» [45, с. 82]. Голова Аннопольської волосної земської управи 8 січня 1918 року доповідав Острозькому повітовому комісару, що «солдати, які прибули додому, здебільшого зі зброєю розповсюджують серед односельців дух більшовиків, які ні законів Тимчасового уряду, ні розпоряджень Центральної Ради не визнають, заявляють, що розпорядження обов'язкові для місцевого населення лише ті, які вони самі створюють. Тому волосна земська управа ігнорується, а замість неї в кожному селищі сільській комітет виконує функції і земельного комітету на чолі із сільським комісаром, який обирається майже кожен місяць» [46, с. 109].

Не кращою була й ситуація на Херсонщині. Тут питання про долю земських управ, міських дум стало предметом обговорення на губернських і повітових з'їздах Рад. Так, 7 лютого 1918 року відбувся Херсонський з'їзд селянських депутатів, де вирішувалося питання про подальше управління земським господарством. Після прочитаних доповідей, 3'їзд постановив: «Повітове і волосні земські самоврядування як такі, що не відповідають вимогам революційного народу і мають у своєму складі представників паразитичних класів [...] ліквідувати в міру організації радянської влади, негайно. Апарати ж самоврядувань зберігаються як секції Рад. Усі справи земського господарства: повітового і волосних переходять у розпорядження всього населення в особі Рад» [47, с. 232].

Висновки. Таким чином, повітові та волосні земства Української Народної Республіки після окупації іiі території військами більшовицької Росії розділили долю своїх губернських візаві - вони були ліквідовані як демократичні органи місцевого самоврядування сільського населення. Ідеологічне та політичне несприйняття земств більшовиками загалом, імплементація земств України в контекст Української революції, зокрема, визначило той радикалізм, до якого вдавалися окупанти та місцеві колабораціоністи особливо у ставленні до повітових та волосних земств, які були найтісніше зв’язані з місцевим населенням.

\section{ЛІТЕРАТУРА}

1. Гамрецький Ю. До питання про встановлення влади Рад на місцях. У боротьбі за Жовтень. Київ. 1981. С. 39 - 52.

2. Гамрецький Ю. М. Ради робітничих депутатів України в 1917 р. (Період двовладдя). Київ: Наукова думка, 1966. 218 с.

3. Харитонов В. Л. Лютнева революція 1917 року на Україні. Харків: ХДУ, 1966. 258 с.

4. Андреев А. М. Местные Советы и органы буржуазной власти (1917 г.). Москва: Наука, 1983. 331 с.

5. Молостов В. А. За владу Рад! Боротьба трудящих України за перемогу Великого Жовтня і зміцнення Радянської влади (1917 - 1920 р.р.). Український історичний журнал. 1968. № 3. С. 148 - 149.

6. Тригуб П. М. Ліквідація міських дум і земств у період боротьби за встановлення і зміцнення радянської влади на Україні (грудень 1917 р. - березень 1918 р.). Питання історії народів СРСР. Харків. 1972. Вип. 13. С. $24-31$.

7. Солдатенко В. Ф. Українська революція. Історичний нарис: монографія. Київ: Либідь, 1999. 976 с.

8. Верстюк В. Українська Центральна Рада: навчальний посібник. Київ: Заповіт, 1997. 341 с.

9. Турченко Ф. Г. Українська революція: 1917 - початок 1918 р. р.: Проблеми, пошуки, узагальнення. Запоріжжя: Просвіта, 1998. 262 с.

10. Томюк І. М., І. Д. Антоник. Військово-політична діяльність у період становлення влади Української Центральної Ради. Військово-науковий вісник. Львів, 2008. Вип. 10. С. 201 - 213.

11. Герасименко Г. А. Земское самоуправление в России. Москва: Наука, 1990. 264 с. 
12. Ревегук В. Полтавщина в українській революції 1917-1920 pр. Полтава: АСМI, 1996. 100 с.

13. Лозовий В. С. Ставлення селянства України до влади в добу Центральної Ради (березень 1917 - квітень 1918 р.р.): дис. ...д-ра іст. наук: 07.00.01 / Нац. пед. ун-т ім. М.П. Драгоманова. Київ, 2010. 466 с.

14. Гвоздик В. С. Земства України в умовах революційних потрясінь 1917 року. Наукові праці історичного факультету Запорізького національного університету. Запоріжжя. 2010. Вип. XXIX. С. 98-105.

15. Гуцалюк I. О. Українські національні органи влади на Волині (1917-1921 рр.): автореф. дис. ... канд. іст. наук: 07.00.01 / Київський нац.ун-т ім. Т. Шевченка. Київ, 2013. 17 с.

16. Козаченко А. І. Земське самоврядування та встановлення більшовицької влади на території Полтавської губернії (1917 - 1920 р.р.). Вісник академії правових наук України. Харків. 2009. № 4 (59). С. 79 - 87.

17. Верховцева І. Діяльність земств Правобережної України (1911 - 1920 рр.): дис. ... канд. іст. наук: 07.00.01 \Ізмаїльський держ. гуманітарний ун-т. Ізмаїл, 2004. 240 с.

18. Стецюк В. Б. Земства Правобережної України в період української національно - демократичної революції 1917 - 1920 рр: дис. ... канд. іст. наук: 07. 00. 01 / Кам’янець-Подільський нац. ун-т ім. I. Огієнка. Камянець-Подільській, 2008. 240 с.

19. Ленин В. И. Гонители земства и Аннибалы либерализма: Полное собрание починений: в 55 т. Москва: Изд - во политической литературы, 1958 - 1965. Т. 5: Май - декабрь 1901. 557 с.

20. История гражданской войны в СССР. 1917 - 1922: в 4 т. / ред. С. Д. Найда. Москва: Госполитиздат, 1958. Т. 3: Упрочнение Советской власти. Начало иностранной военной интервенции и гражданской войны (ноябрь 1917 г. - март 1919 г.). 679 с.

21. Комиссародержавие. Наша борьба. 1918. 19 февраля. (№ 210). С. 4.

22. Раскассирование волостных земств. Жизнь России. 1918. 5 марта. (№ 22). С. 4.

23. Земство разрушается. Жизнь России. 1918. 23 февраля. (№ 15). С. 5.

24. Копії матеріалів про боротьбу за встановлення влади в Україні // ЦДАГО України (Центральний державний архів громадських об’єднань України). Ф. 5. Оп. 1. Спр. 6. Арк. 10.

25. Прийняття до відома і керівництва урядовими розпорядженнями // ЦДАВО України (Центральний державний архів вищих органів влади та управління України). Ф. 1556. Оп.1. Спр. 1. Арк. 3.

26. Наш край. Народная жизнь 1918. 19 февраля. (№ 25). С. 4.

27. Земская жизнь. Верхньодніпровське життя. 1918. 18 квітня. (№ 2). С. 4.

28. В уездной земской управе. Народная жизнь. 1918. 11 апреля. (№ 42). С. 3.

29. Табаков 3. Октябрьская революція в Черниговщине. Летопись революции. 1922. №1. С. 143-170.

30. Циркуляр виконавчого бюро Новозибківської повітової Ради робітничих, солдатських та селянських депутатів про організацію органів радянської влади в повіті. Борьба трудящих ся Черниговщины за власть Советов 1917 - 1919 г.г. Сборник документов. Чернигов: Облтипография, 1957. 475 с.

31. Гласным Сосницкого земства и всем гражданам от Сосницкой уездной земской управы. Черниговская земская газета. 1918. 1 марта. (№ 13 - 14). С. 5.

32. Щербаков В. Жовтневий період на Чернігівщині. Літопис революції. 1928. № 1 (28). С. 115-137.

33. Про волосне земство // ЦДАВО України. Ф. 1523. Оп.1. Спр. 22. Арк. 15.

34. Оповіщення. Рідний край. 1918. 15 квітня. (№ 11). С.2.

35. Події останнього часу. Рідний край. 1918. 31 січня. (№ 4). С.2.

36. Большевики и Украина. Народная жизнь. 1918. 20 января. (№ 12). С. 4.

37. Виписки з газет про боротьбу Червоної армії з німецькими військами; опір селян і робітників Полтавщини проти німецького окупаційного уряду, про створення органів Радянської влади на місцях // ДАПО. Ф. п-7. Оп. 1. Спр. 42. Арк. 61-63.

38. Чернухское волостное земство. Лохвицкое слово. 1918. 9 февраля. (№ 9). С. 4.

39. Кризис Свиридовского земства. Лохвицкое слово. 1918. 30 января. (№ 6). С. 3.

40. Лукское земское собрание. Лохвицкое слово. 1918. 27 февраля. (№ 13). С. 5.

41. Доклади Кременчуцької повітової земської управи // ЦДАВО України. Ф. 1618. Оп. 1. Спр. 2. Арк.. 25.

42. Виписки з газет про боротьбу за встановлення радянської влади на Полтавщині, створення органів радянської влади в Хорольському, Миргородському, Лубенському та інших повітах // ДАПО. Ф. П7. Оп. 1. Спр. 41. Арк. 52-55.

43. Андрієвський В. 3 минулого. Нью-Йорк: Горевля, 1963. Т. 2: 1917 рік на Полтавщині. 209.

44. Дем'янюк О. Волинська губернія в січні - лютому 1918 р. Наукові записки національного університету «Острозька академія». Історичні науки. 2009. Вип. 14. С. 134-142.

45. Прищепа О.П. Діяльність земств на Рівненщині. Наукові записки. Рівненський краєзнавчий музей Рівне, 1996. Вип. 1. С. 76-84.

46. Донесення Аннопольської волосної земської управи. Борьба трудящих ся Волыни за власть Советов (март 1917 г. - декабрь 1920 г.). Сборник документов и материалов. Житомир: Житомирское областное изд-во, 1957. $480 \mathrm{c.}$

47. Резолюция Херсонского уездного съезда Советов крестьянских депутатов о создании органов Советской власти в уезде. Борьба за Великий октябрь на Николаевщине (февраль 1917 г. - март 1918 г.). Сборник документов и материалов. Николаев: Партийный архив Николаевского обкома КП Украины, 1957. 303 с. 